\title{
Analysis of strong motion records of the Cephallenian shock occurring on Sept. 17, 1972 and of its larger aftershock
}

\author{
J. Drakopotilos $\left({ }^{*}\right)-A$. Rotssopotilos (**)
}

Received on Auguat 1st, 1973

\begin{abstract}
Sumanr. - In the present paper the first strong motion actelero. grams from the area of Greece are analfsed. The general information of the main slioek and the larger aftersliock are also introduced. Curent elata processing techniques for strong motion acelerograms and modern im. provenemts in data recovery capabilities are alisenssed. The analysio of the recorded strong motion aceelerograms were accomplisherl by digital com. puter and the main seismic characteristics of the ground motion were ol)tained such as: period-frequeney analysis, probability-density distribution, auto-correlation function, power spectral density, gromul acceleration, velocity anl displacencut, response spectra ele. Soune useful information about the nature of the motion of the gromel have been taken from this inverstigntion.
\end{abstract}

Riassexto. - Sella presente nota vergono andizzati per la prima volta acederogramui "strong motion sotennti in Grecia, con le relative generali informazioni sulla scossa principale e sulle repliehe piu forti. Fengono inoltre discussi le teenicles attuali per la trattazione dei dati da aceelerogrammi astrong motion n, nonehe i moderni progressi raggiunti per la reperibilità dei lati stessi. L imalisi delle registrazioni "strong notion * è stata efletenata a mezzo di clahoratore digitalizzato che laz fornito le prineipali maratteristie he sismiche del movimento del stolo, ciod: analixi periodo-freguenza, distribuzione probabilitidensiti, funzione di anto-eor. relazione, spettro ti potenza, acererazione del suolo, velociti c spostancuto, spettro di risposta de... Da questa rieerea si somo asute utili informazioni sullit natua del movimento del suolo.

(*) National Observatory of Athens, Thission, Athens, Gieece.

(**) Nutional Technical Liniversity of Athems, Athens, Greece. 


\section{1. - INTIODLCTION}

Soismologists and earthquake engineers except of the other fichds of their sciences stury the intensity of soisnde whes and mainly the ground acceleation associaleal with llese, since they are interested in the elfeed that enrthoules have on structures. Appraisal of these ell'ertis is possible by measuring the value of acceleration.

Strongr molion instruments oller themselves for such measurements, as they generally record the accelerat ion associnterl with strong ground movements. The development of instrumentation for the letection and recoraling of local earthquas by strong motion instruments began just after 1932 . The first accelerogram was obtained in 1933 during the Longr-Bencl earllogulke in Californin, and since then about 500 valuable records have been olotained by the C.S. Coast and Geodedic Survey of earlliquakes of a destructive or potentially destructive size. About one-lanlf of these records were obtained during 1 te San Eermando earthutake of Febr. 9, 1971 and of these 250 records some 120 were recorded in the upper floors of high-rise buildings ("). Smaller numbers of records were obtainer for other important eart. $l_{-}$ quakes. The limitesl number of strong motion rerords wlich exist give us an irlea of the importance of them.

Computer methods facilitate immensely the use of recorded data, their classifiontion and the calculation and analysis of the main seismic claracteristics of the ground. By molern data processing techniques t. Ine acolerograms an be integrated to probluce ground velocities and displacement with a satisfaclory aeculacy. A fligitized acederogram cannot be integrated immediately in an attempt to aletermine ground velocity and displacoment for the following reasons. The initial veloeity and displacement and the actul zero base line for the digitized accelerogram are not known. Of these three unknowns, finding the zero base line of the accolerogram is the most important step in accelerogram data processing.

By the use of high-resolution aligritizntion and aligital filtering it is possible to remove random errors from the recorals to the point tlat integrations and aflerentiations an be carried out over prescriber fresueney clomains (5).

The mosi complete rescriplion of eathquake arromen motion is the accelerogram itsell which expresses the full time listory of the true ground acesleration. The most simple way to lave in a guanti- 
tative way the efiect of an authquake on structure is the peak horizontal ground acceleration which is readily available from the accelerogram and it is commonly thoughit to be elosely related to the lateral forces on a structure. This is in fact the case for high-frequeney systems, but for intermediate and low frequeney structures, which include most buildings and engineering works, the ground acceleration is not even an approximate indication of the actual lateral earthquace forces. A better overall picture would be obtained by specifying as well the maximum ground velocity and the maximum ground asplacement, as these quantities would sample respectively the intermediate frequency and the lower frequency regimes (5). If one single ground parameter must be insisted upon, it appears that the peak ground velocity would probably be the best. As has been shown by Hudson (') this peak ground velocity is commonly userl to express the damaing potential of sloocks and is correlated at least roughly with the Morlified Mercalli intensity.

In the present paper the first motion accelerograms from the area of Greece are analysed and comparesl. So some useful information about the nature of the motion of the ground lave been taken from this investigation.

\section{2. - INstrumevation}

Some countries, such as U.S.A., Japan, U.S.S.R. and others witl high technical knowledge and experience, have rleveloped various types of strong-motion instruments in order to face the destructive eartlıquakes which occur.

The basic instrument for strong motion seismology is the strong motion accelerograph, which recorts three components of ground acceleration versus time. The SHAC-B type accelerograph which las been installed on Ceplallenia records ground acceleration up to $1 \mathrm{~g}$ with a resolution of the orrler of 1 gal. $A$ vertical electrodynamic starter is used which has a flat frequency from ahout 1-10 CPS and ran be set to trigger at aceelertion level above 5 or 10 gal. So the recording is make automatically when an earthquake of more than 5 gals takes place and the four subsequent large eartliquakes can be recorder in the event that the scismograph cannot be inspected immediately following the large earthquake.

A simplifierl instrumentation network consisted of 27 seismoscopes lave been installed in Western Grece. Four seismoseope records 
were obtained during the Cephallenian main shock at sites having varying local soil and geological conditions and so some additional ground motion distributions were ascertained as for example the attenuation of ground motion witl distance can be clearly seen.

This type of seismoscope consists of a conical pendulum free to move in any horizontal alirection about a pivot point which is aftached to the ground. The pendulum has an undamped period of 0.75 secomsts and magnetic damping of $10 \%$ critical. The two-rimensional lorizontal response is maked out by a stylus on a smoked spherieal watel glass. The seismoscope can be regarded as a dymamic model of typical structure sund from its response, one point on the response spectrum eurve is directly defermined. The amplitude of the seismoseope record thus indientes the relative severity of the ground motion in the frequency range of structural interest $\left(^{5}\right)$. The seismoscope, of course samples the ground motion at just one frequency allhough the amount of damping is such tlast major lluctuations of response

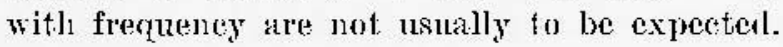

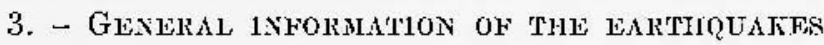

At 14 hours $07 \mathrm{~min}$, G.M.T. on September 17,1972 a large earthquake occurred near the Western coast of Ceplatlenia. Island. USCGS calculates the epicenter at $38.3^{\circ} \mathrm{N}, 20.3^{\circ} \mathrm{E}$; BClS and the seismologion. institute of the National Observatory of Athens caleulated the same epicenter at $38.2 \circ \mathrm{N}, 20.4^{\circ} \mathrm{E}$. The shock produced property damages in several localities, in Southwestern pat of the Cephallenia island. Accomling to official reports 108 old houses were damaged beyond repair and 53 were eracked. In aldition 2 sehool builulings 2 eluuches and 2 bridges were crucked.

The rather extensive property damage only in some old buildings is attributed principally to poor construetion of these buildings in the region. However the location of some of the villages on alluvium was a contributing factor in these instances. It is not our intent to elaborate further on the ramage to specific buildings.

In Fig. 1, the isoseismal map of the earthquake on MercalliSieberg scale is illustrated with some additional necessary seismologionl information. Area of felt shaking about $720,000 \mathrm{~km}^{2}, r_{5}=280 \mathrm{~km}$. Macroseismic magnitule $M . M=6.8$ and macroseismic focal depth ca $60 \mathrm{~km}$. The instrumental magnitude was 6.2 . 


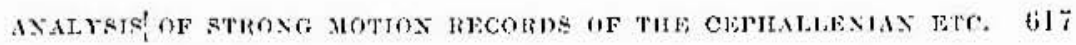

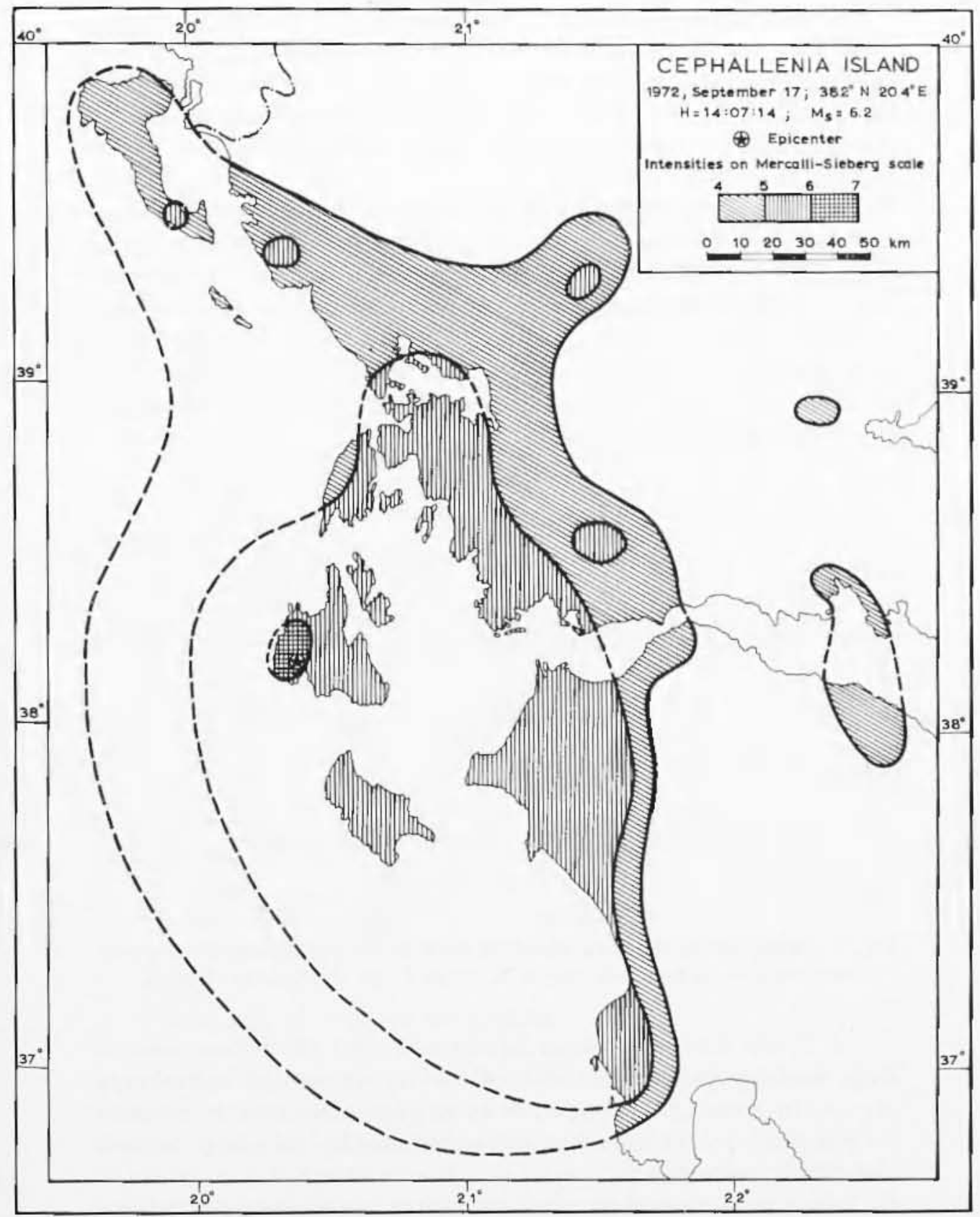

Fig. 1 - Isoseisnal nap of the Cephallenian main shock of September 17, 1972. 
Accelerograms of the earthquake are shown in Fig. 2. These records are from a SHCAC-I3 type strong motion seismograpl installed at Argostolion $\left(38^{\mathrm{u}} 10^{\prime} \mathrm{S}, 20^{\mathrm{a}} 36^{\prime} \mathrm{E}\right)$ on Cephallenia island. Calibration of the SMLAC recorils were male and results revealed no particular defect with exception of the vertical component which fateal to record distinetly.

The epicentanl distance was about $30 \mathrm{~km}$. It must be mentioned liere that the foumbation at the site of strong motion seisunggraph is limestone. By those records (fig. 2) the following fuct became cleur that the maximum acceleration directly measured by the accelerograms was 170 gals in F-W component while 130 gals was the maximum in N-S component and duration of the tremor of which amplibude excesested more than 100 gals continued for more than 2.5 seconds in horizontal eomponents.
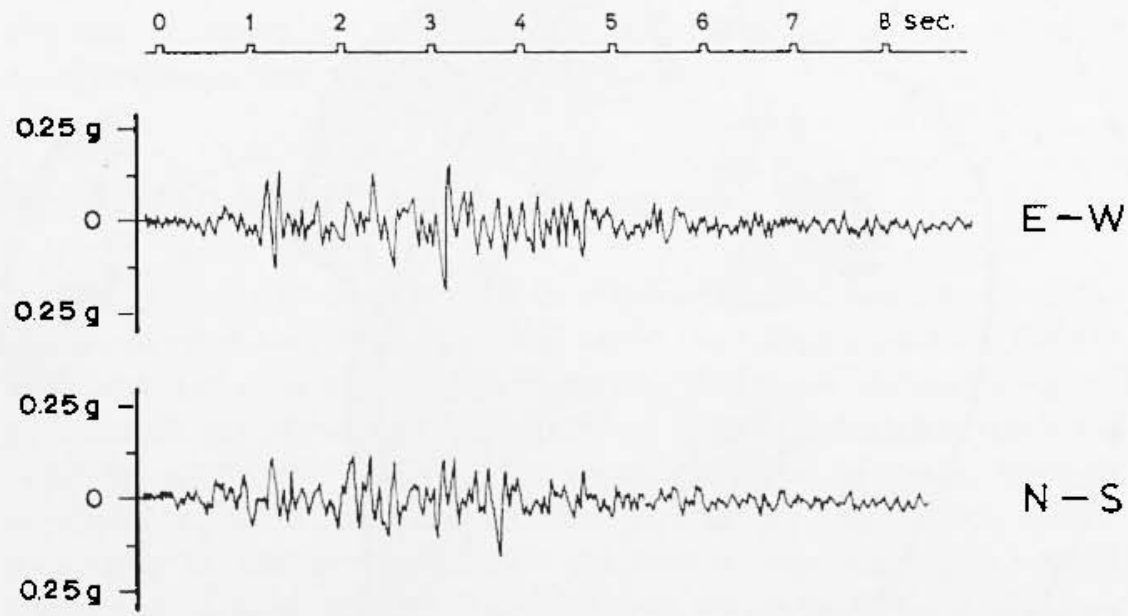

Fig. 2 - Reeords for the main shock of a SMAC-B type strong motion seismograple at $A$ rgostolion $\left(38010^{\prime} \mathrm{N}, 20^{\circ} 36^{\prime} \mathrm{E}\right)$ on Cephallenia Island.

A $12 \mathrm{~mm}$ N100"E full-scale deflection of a SR-100 Wilmol seismoscope was observed at the site of the sirong motion seismograph (fig. 3). In Mresologhli $\left(38^{\circ} 36^{\prime} \mathrm{N}, 21{ }^{\circ} 45^{\prime} \mathrm{E}\right)$ and Zante $37^{\circ}+6^{\prime} \mathrm{N}, 20^{\circ} 56^{\prime} \mathrm{F}$ ) the recording pen of the seismoscopes deflected by $2.5 \mathrm{~mm}$ in N1.50 $\mathrm{E}$ and $\mathrm{N} 26 \mathrm{H}^{\circ} \mathrm{E}$, respectively.

Since these two lastly mentioned sites are in almost equal distances from the foci and in a different oriendation relatively to the probable fault, we may say that the values altenuate with distance in a fairly uniform way. There is strong evidence by the distribution 
of the epicentres of aftersllocks that the fault is in a rlirection NXW and if this is true, it is difficult to say if the motions were more severe perpenelicular to the fault than parallel to it.

A late aftershock occured on Oet. 30 (1.th $32 \mathrm{~min})$ with almost the same epicenter and magnitude of 5.J. Area of felt slaking about $180,\left(100 \mathrm{~km}^{2}, r_{5}=120 \mathrm{~km}\right.$ (fig. 4). Accelerograms of this a.ftershock by the same SMAC-B type strong motion seismograph installed at the same place are indicated in fig. 5.

This aftershock prorlucer a $\mathrm{N}^{\top} 90^{\circ} \mathrm{E}$ full-seale deflection of the SR-100 Wilmot seismoscope assigned at Argostolion by $7 \mathrm{~mm}$.

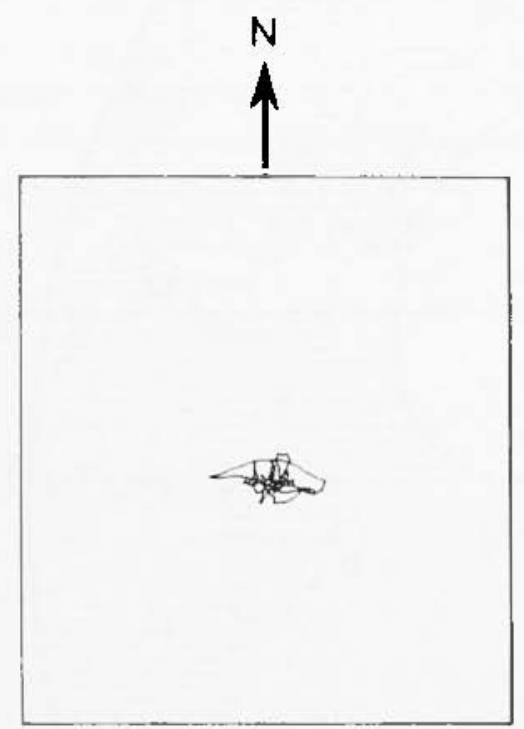

Fim. $3-A 12 \mathrm{~mm}$ N $100^{\circ} \mathrm{E}$ full-scale deflection of a SR-100 Wilmot seismoscope installes at the site of the strong motion seismograph.

\section{4. - ANALYSIS OF THE ACCELEROGTAHS}

In figs $6 \mathrm{a}$ and $6 \mathrm{~b}$ probability-rensity distribution of the E-W and $\mathrm{S}-\mathrm{S}$ accelerogram are shown corresprondingly.

In figs $7 a$ and $i b$ are shown the power speetral density plots of the E- $\mathrm{W}$ and $\mathrm{Y}-\mathrm{S}$ components. Is it is clear from these figures the predominant frequencies in the two horizontal conponents were $2 \mathrm{cps}$ for E-W and $+\mathrm{cps}$ for $\mathrm{N}-\mathrm{S}$ component. Tlus the spectrat the site are concentraterl around the periods $0.5 \mathrm{sec}$ in $\mathrm{E}-\mathrm{W}$ component and 0.25 see in $\mathrm{N}-\mathrm{S}$ component. 


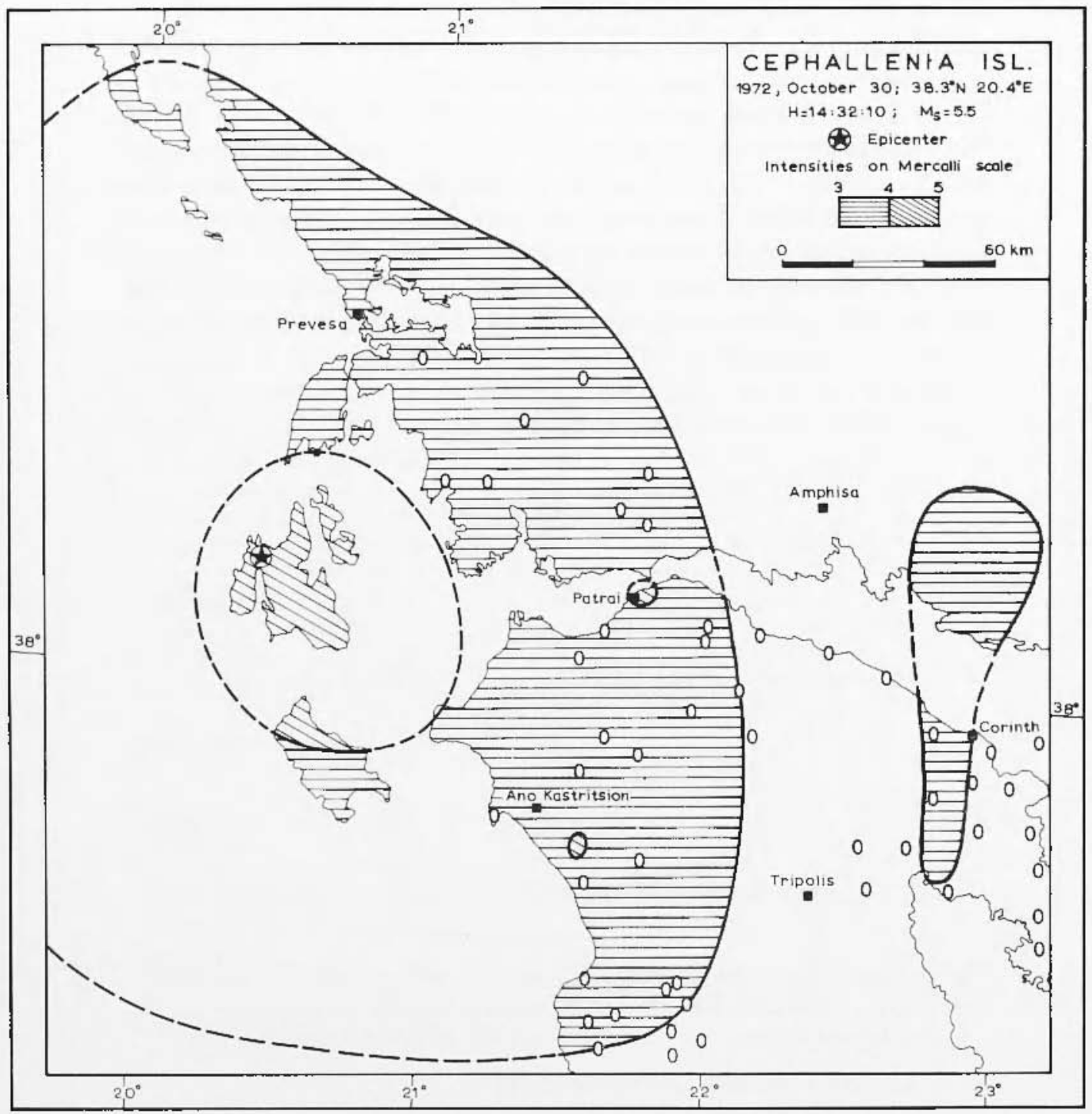

Fig. 4 - Isoseismal map of the late aftershock of October 30, 1972.

So it is clest that these is not eoincidence of the prodominant periosls of the earthquake in both horizontal components. In figs $8 \mathrm{a}$ and $8 \mathrm{~b}$ you can see the modified power spectal density of the F-W and N-S components correspondingly. 
The Fourier spectral tensity functions of the two components are inticated in the figs $9 \mathrm{a}$ and $0 \mathrm{~b}$ for the $\mathrm{E}-\mathrm{W}$ and $\mathrm{N}-\mathrm{S}$ components correspondingly. From the fig. $9 \mathrm{a}$ it is concluded that the period for main max. is 0.50 sec while two other seconfary maximum are in periorls 0.30 see and 0.15 sec. From the fig. $9 \mathrm{~b}$ it is elear that the period for main max. is $0.25 \mathrm{sec}$, and spectra are also concentrated around the periorls $0.40 \mathrm{sec}$ and $0.15 \mathrm{sec}$.

Wr olstained the same plots for the larger aftershock. What it is worth to mention from the results is that the pretominant periods are comparatively smaller in the corresponding components iluring the aftershock. The ratio of the main shock predominant period to that of the aftershock for E-W component was 1.34 and for $N$-S component was 1.47 .

Another important observation for the aftershock is the alssence of well expressed secondary maximum for otlier periods. That is mainly due to the small duration of the record.
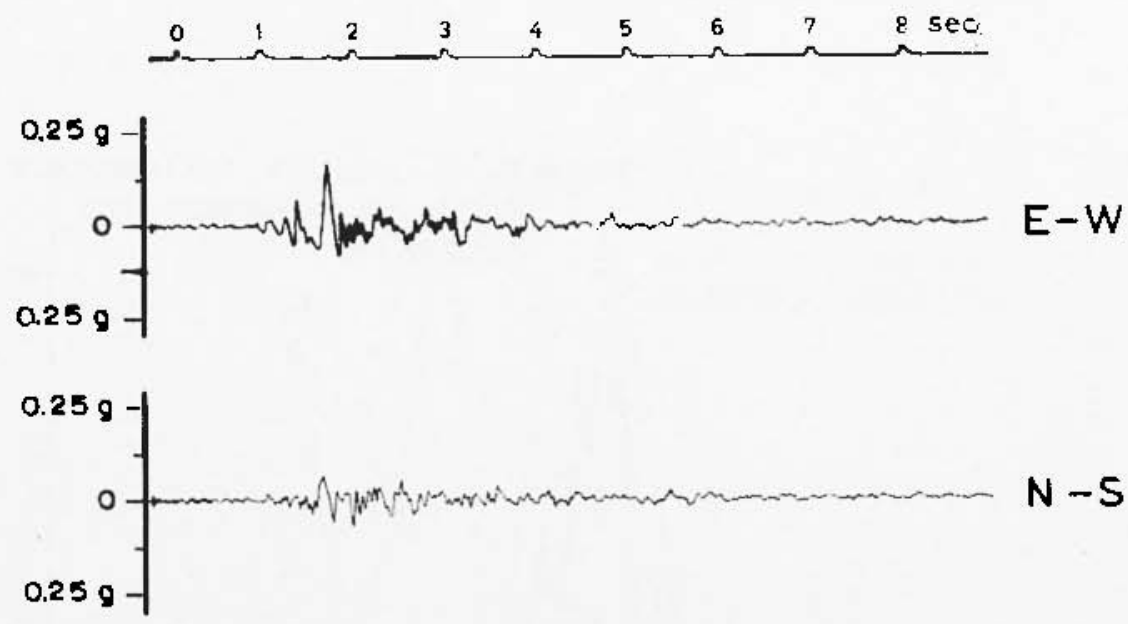

Fig. 5 - Records for the late aftershock of a SMLAC.J3 strong motion seismograph at $\mathrm{Argostolion}\left(38^{\circ} 10^{\prime} \mathrm{N}, 20^{\circ} 36^{\prime} \mathrm{E}\right)$ on Cephallenia IsIand.

\section{5. - TRESPONESE SPECTRUM}

The response spectra of earthqualie ground motion is defined as the plot of the maximum response of a series of a single tlegree of frediom, linear, viscously damper oscillators to a preseribed ground 

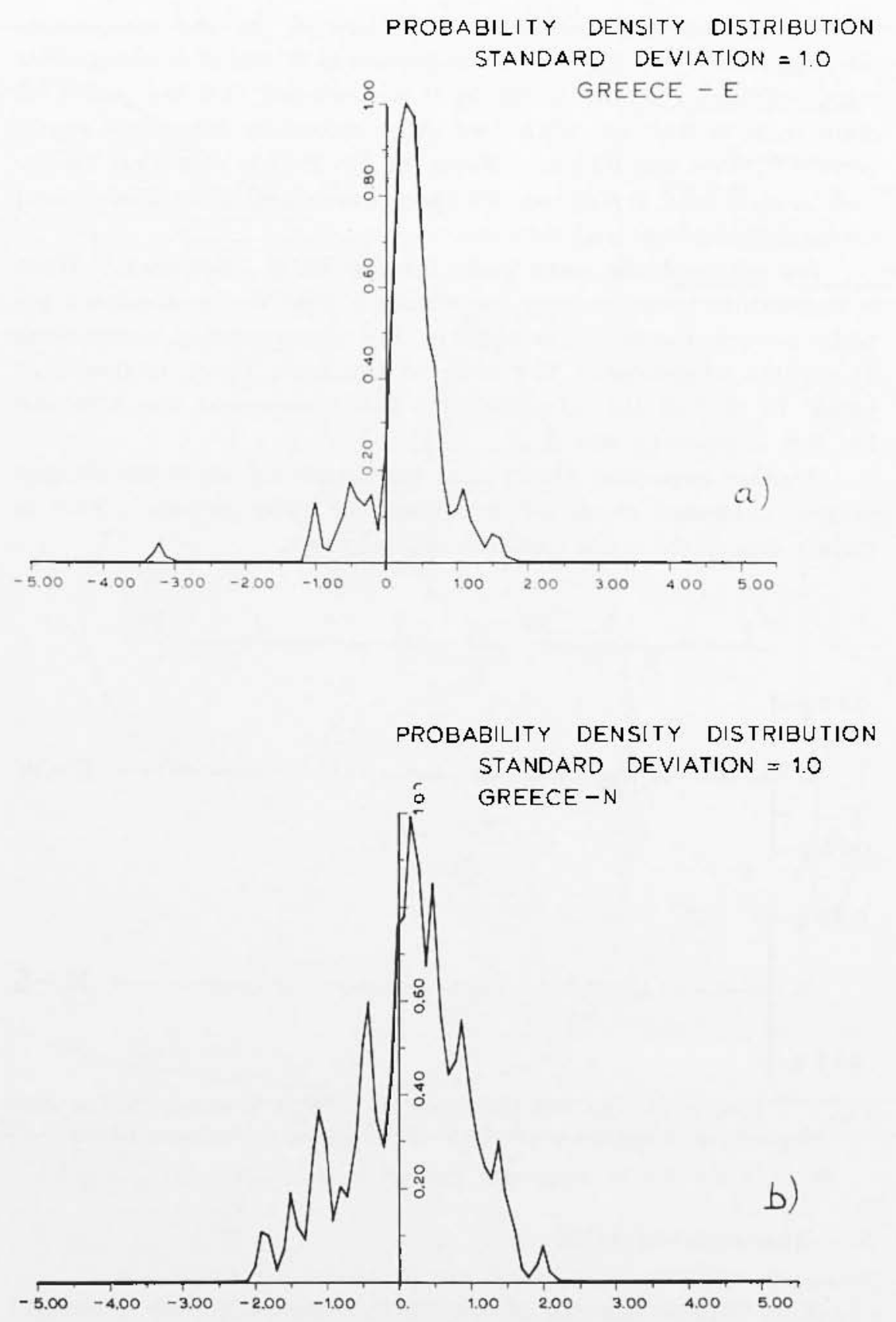

Fig. (6 - Probability density distribution of the main shoek for the F.W (6a) anil N-S (6b) accelerograms. 
ANALYSIS OH STRONG MOTION RECORDS OF THE CEPBALILNAN ETC. 623
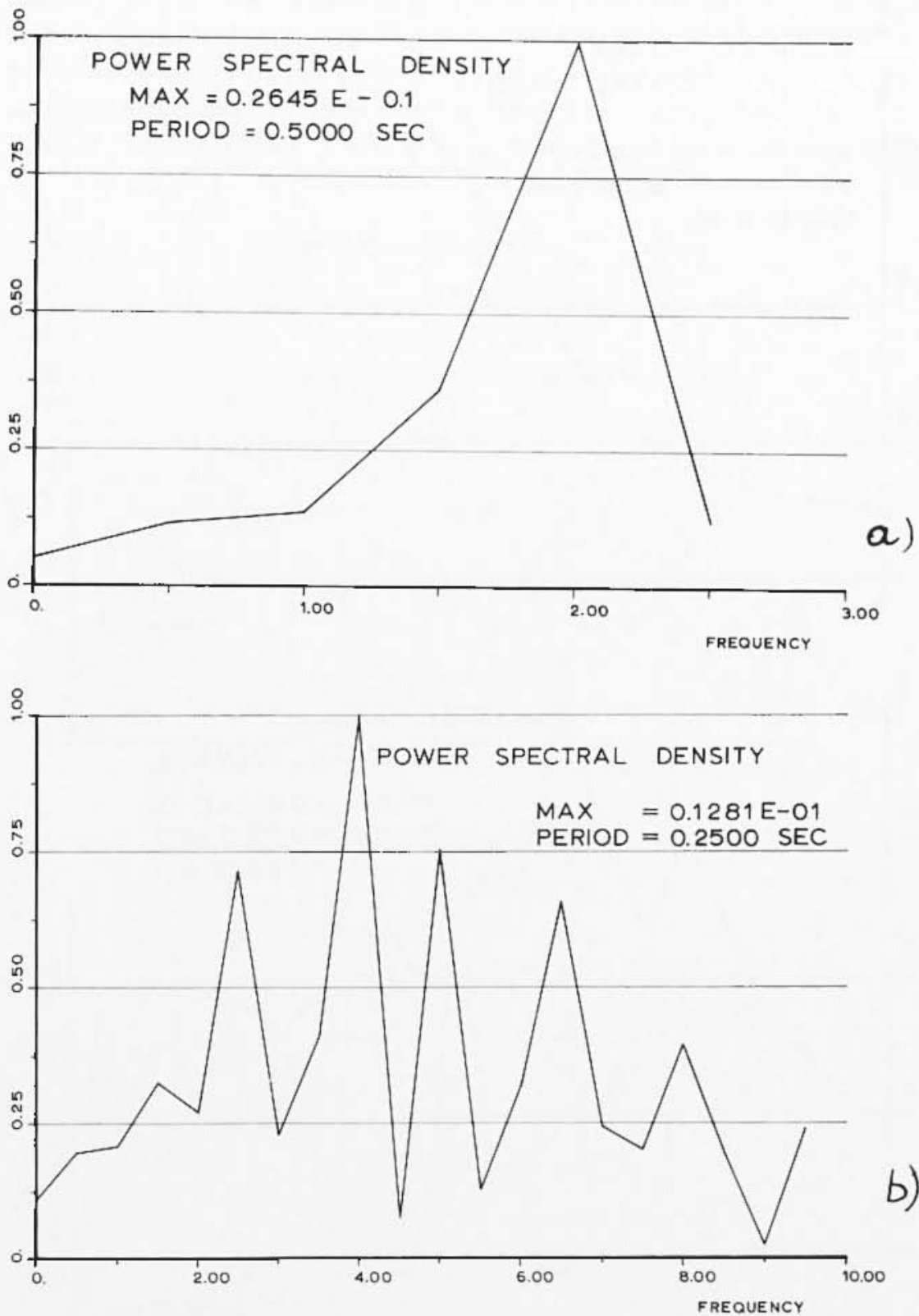

Fig. 7 - Power spectral density of the main shock for the E-W (7a) and N.S $(7 \mathrm{~b})$ accelerograns. 

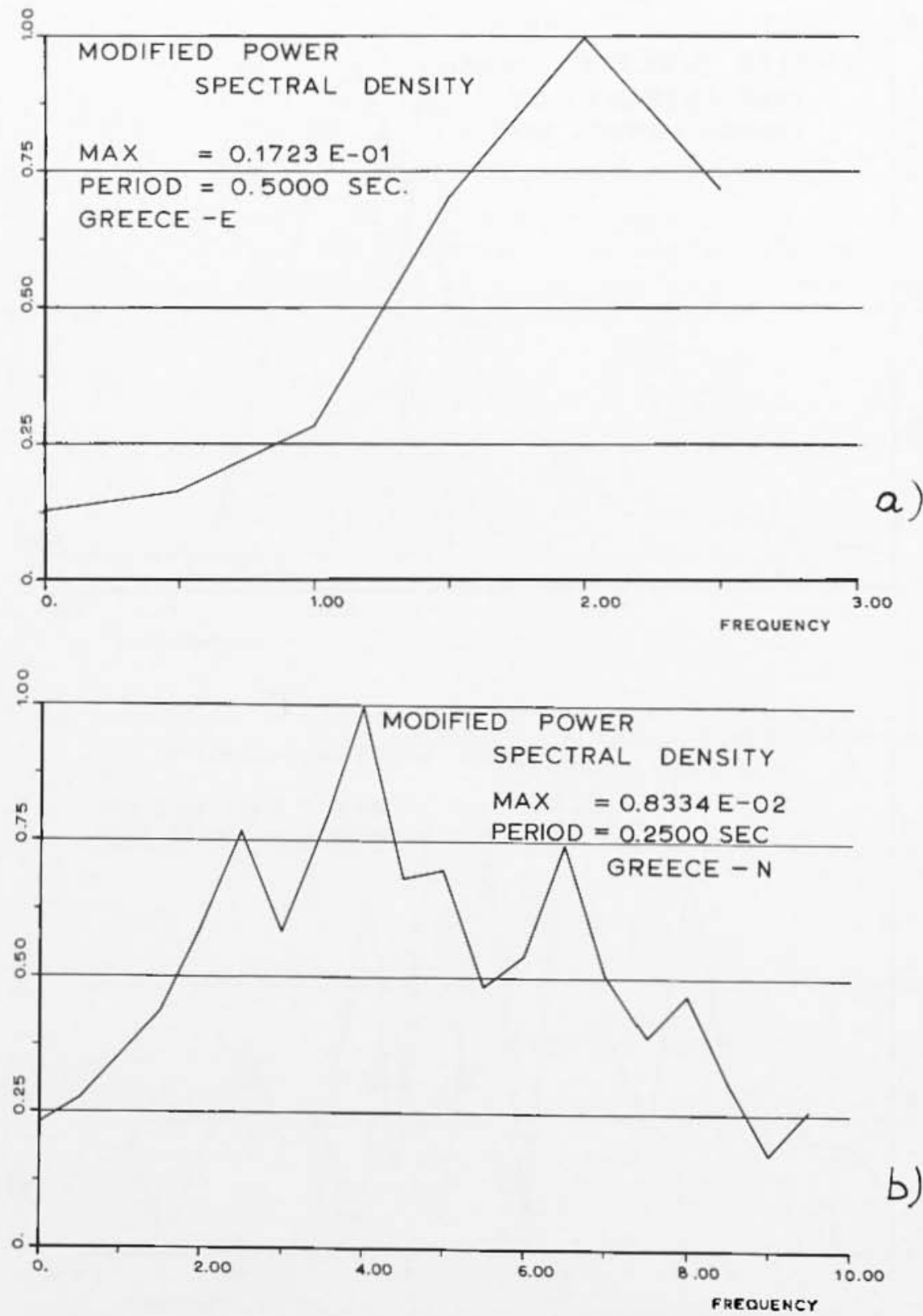

Fig. 8 - Modifiel power spectral density of the main shock for the L-W (8a) and $\mathrm{N} \cdot \mathrm{S}(811)$ aceelerngrams. 
motion, versus lite natual period of the oscillator for various frac1.ions of eritical alamping. The response spectra can be expresseal in lerms of relative displacement, relative velocity and relative or absolute acceleration. These curves proviste a slescription of the frequency chatacteristics of the ground motion and give the maximum

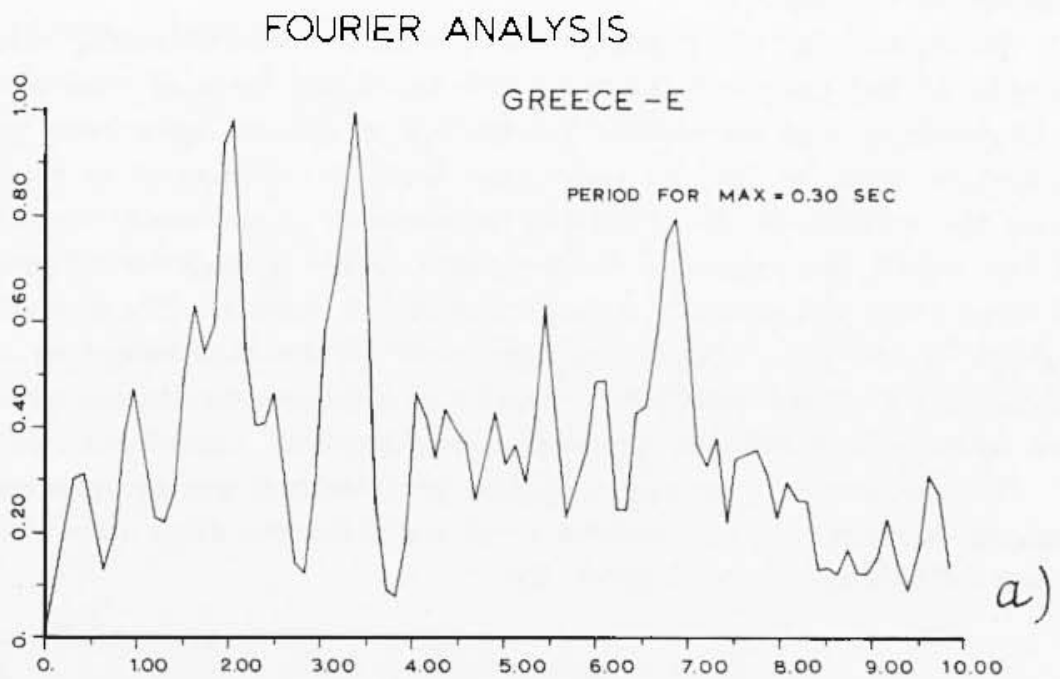

FOURIER ANALYSIS

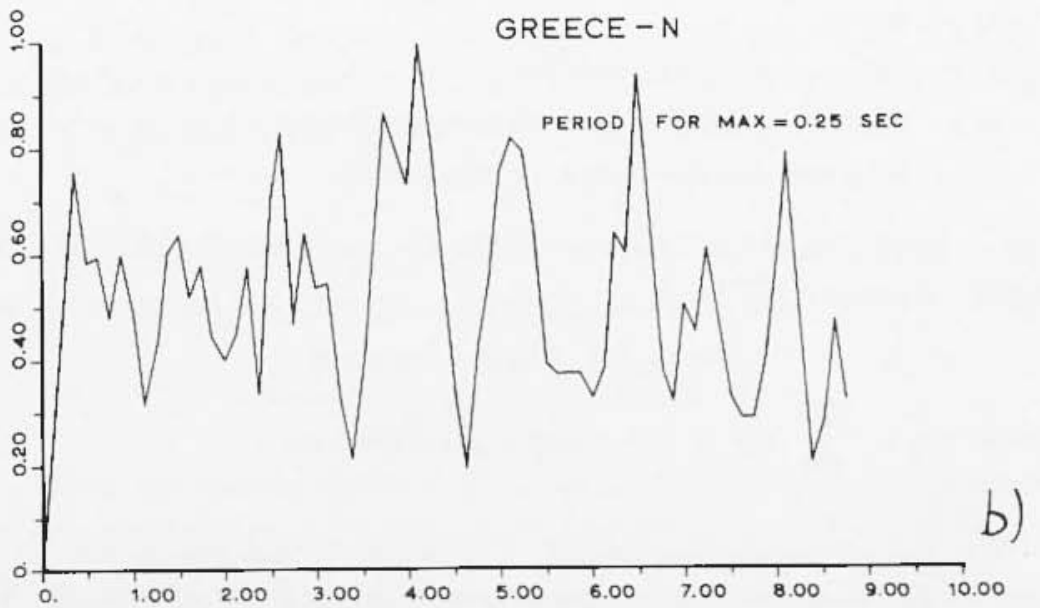

Fir. 9 - Fourier spectral density function of the main slock for the E.W (9a) and N-S (9b) accelcrograms. 
response of simple structures to the earthruake. By superposition of different modes of response, spectrum techniques can be applied to the design and analysis of complex struetures such as multistory buililings ant clams. Lserl in this manner the spectrum technique represents an approach intermediate between a design based on static loads and a complete integration of the equations of motion of the complex strictures $\left({ }^{2}, 5\right)$.

Strong-motion earthquake records have been obtained infrequentily in the past and the reduction to rigital form or equivalent analogue form and subsequent calculation of spectra have been performed on more or less an indiridual basis ( $\left.{ }^{6}\right)$. However, in recent years the number of strong-motion instruments in the seismic regions of the world, has increnset to the point where a major orthiqunke in these areas will generate a large number of records. The potential volume of the data and the derelopment of the tape-recording accelerograph inclicate clearly that rapicl and automated data processing and spectrum calculation procedures aro needet.

The response of a single ilegree of freedom, linear, viscously damper system, at any instant $t$, to an arbitrary timo ilepentent ground displacement $u_{0}$ is given by

$$
m \frac{d 2}{u v^{\prime \prime}}\left(u+u_{0}\right)+C \frac{d u}{d t}+K u=0
$$

Where

$$
\begin{aligned}
& m-\text { mass. } \\
& C=\text { viscons damping coefficiont. } \\
& K=\text { coefficient of stiffness of the system. } \\
& u=\text { relative displacement of the mass. }
\end{aligned}
$$

$u_{o}(t)=$ displacement of the base from the position of rest. We chu simplify equation [1] to

$$
m \ddot{i}+C \dot{u}+\Pi u=-m y(t)
$$

Where $g(t)=\frac{d^{2}}{d t^{2}}\left(u_{0}\right)$ is the grount accoleration.

For the strong-motion records it was found that the accelerogram trace could be approximated quite closely by a series of straight line segments. In that chse it is for $t_{i-1} \leqslant t \leqslant t_{i}, g(t)=a_{t}\left(t-t_{i-1}\right)+b_{i}$, where $a_{i}, b_{i}$, are constants of the $i t h$ segment. 
Csing this assumption it is easier and quicken using computer technique to solve the equation of motion.

By getting the ground arealontion in a digitised form equation [?] can be written as follows:

$$
m \frac{d^{2} u}{d t^{2}}+c \frac{d u}{u i}+K u=-m\left[a_{i}\left(t-t_{i-1}\right)+b_{i}\right]
$$

Equation [3] can be written

$$
\frac{d-u}{d t^{2}}+2 \lambda_{0} \frac{d u}{\ddot{u} i}+w_{0} w^{*} u=-a_{i}\left(t-t_{i-1}\right)-b_{i}
$$

where

$$
w_{\mathrm{u}}^{2}=\frac{K}{m} \quad \text { and } \quad 2 \hat{\lambda}_{\mathrm{o}}=\frac{C}{m}
$$

By getting the solution of the equation for $u$ (relative displacement), $u$ (relative velocity), $u_{a}$ (alssolute accelerution), and witl the initial coulitions known i.e, $u=u=0$ at $t=0$ these values ear be calculated by a step by step process at any required instant.

\section{6. - BASE LINE CORRLCIION}

\subsection{Some basis assumptions}

It is assumerl that the accelerogram is considered as a series of straight lines comnecting eacl peak of it. Tlus starting from the equation of a straight line pussing from two points

$$
y-y_{1}=\frac{y_{2}-y_{1}}{x_{2}-x_{1}}\left(x-x_{1}\right)
$$

the aceleration can be calenlated (fig. 10)

$$
\ddot{u}\left(t_{)}=\frac{\ddot{u}_{t}-\ddot{u}_{i-1}}{t_{i}-t_{i-1}}\left(t_{i}-t_{i-1}\right)+i_{i-1}\right.
$$

Since the accelerogram is given in time-acceleration coordinates, the acceleration can be calculated at any desirable interval of time (6). Thus

$$
\ddot{u}(t+\Delta t)=\frac{\ddot{i}_{i}-\ddot{u}_{i}-1}{t_{i}-\ddot{t}_{t-1}}\left(t+\Delta t-t_{i-1}\right)+u_{i-1}=u(t)+\frac{u_{i}-u_{i-1}}{t_{i}-t_{i-1}} \Delta t
$$


628

.r. MHKOPOTLOS - A. ROTSEOPOLI,
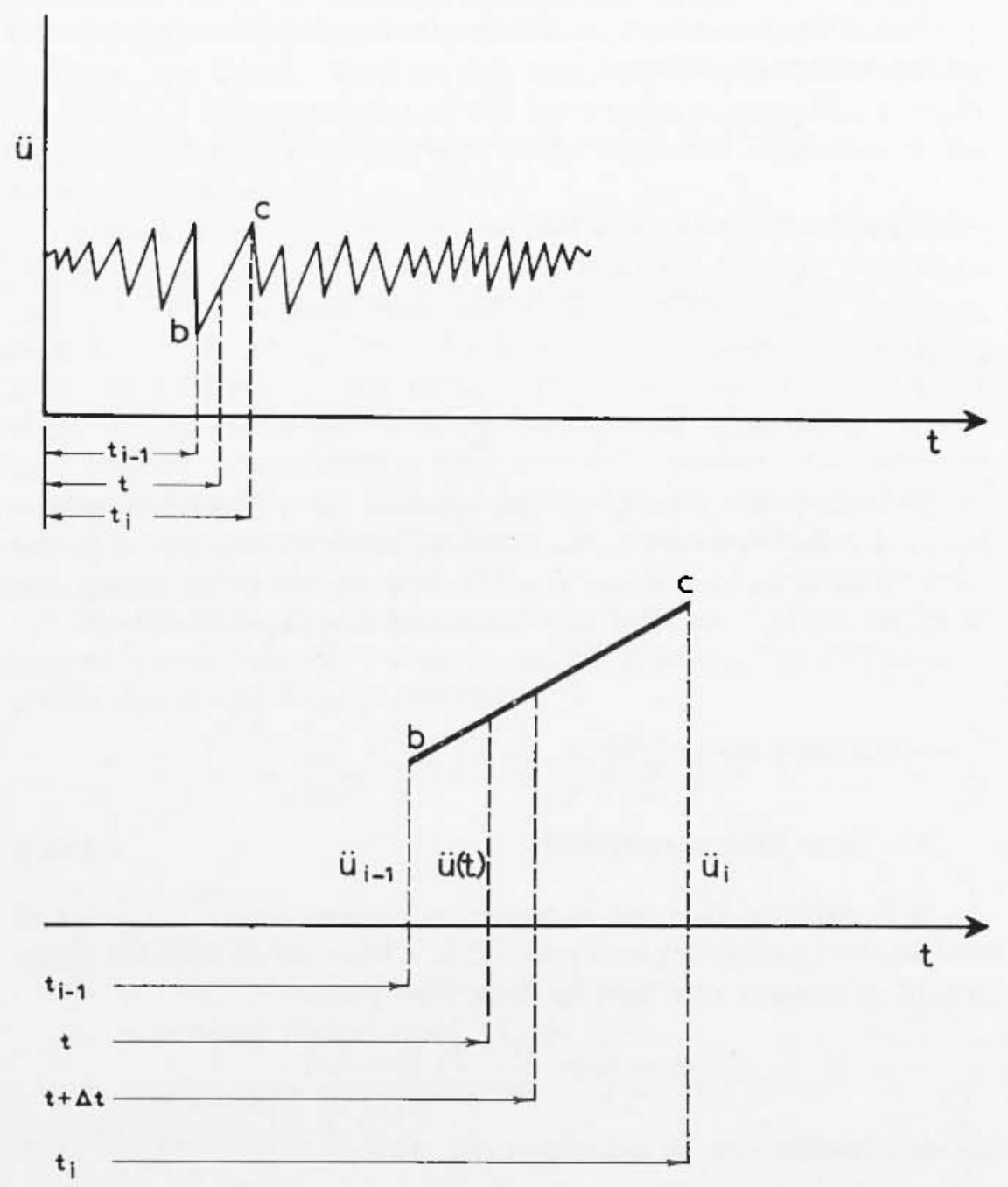

Fig. 10 - Explanation figure in time-acceleration coordinates.

According to Taylor series for " function $F(x)$

$$
F(x+\Delta x)=F(x)+\frac{\dot{H}(x) A x}{1 !}+\frac{\ddot{F}(x) \Delta x^{2}}{2 !}+\frac{\ddot{F}(x) A x^{3}}{3 !}+\ldots \ldots
$$


For the ground velocity

$$
\begin{aligned}
& \dot{u}(t+\Delta t)=\dot{u}(t)+\frac{u(t) A t}{1 !}+\frac{\ddot{u}(t) \Delta t^{2}}{2 !}= \\
& =\dot{u}(t)+\frac{1}{2} \ddot{u}(t) \Delta t+\frac{1}{2} \ddot{u}(t+\Delta t) \Delta t
\end{aligned}
$$

And for the groment ilisplacement:

$$
\begin{aligned}
& u(t+\Delta t)=u(t)+\frac{\dot{u}(t) \leq t}{1 !}+\frac{\ddot{u}(t) \Delta t^{2}}{2 !}-\frac{\ddot{u}(t) \Delta t^{3}}{3 !}= \\
& \quad=u(t)+u(t) \Delta t+\frac{1}{3} u(t) \Delta t^{2}+\frac{1}{(j} u(t+\Delta t) \Delta t^{2}
\end{aligned}
$$

By integration of the straight line of the acceleration we get a curve of and for the velocity and by a new integration of 1lue reloeity we get a cure of $3 r$ for the displacement. Integration ean be carried out much more accurately than differentiation, since it is easier to rletermine the way in which the area unler a complicated curve varies with lime than it would be to measure the slope of the curve.

For further inerease in aceuracy in lhe ealculation of the above quantities it is necessars to apply a basc-line correction to the recorrled acceleration, since no base-line is available straight from the accelerogram; the base-line corraction of the accelertion, influnces the calculation of ground velocity and displacement.

After the calculation of the base-line correction, we can find the points where the acceleration becomes zaro. These points of zero acceleration correspont to maximum ralues of velocity. This is very important especially for the ealculation of the respronse spectra. Wo ean find in this way missing values of velocity which we could not before arljusting the base line (?).

\subsection{Least-Mean-Square-Velocity Technique}

This technique introlucel by Berg and Housner (1), adds a imedepentent second order polynomial $\left(C_{0}+C_{1} t+C_{2} t^{2}\right)$ to the accoleration, giving by this way to the acceleration base-line the shape of a second degree parabola. The technique makes the man square value of the ground velocity a minimum. This is justifien mainly by the feeling that most earthqualie ground motions of significant: time thration correspont to gromul velocities which oscillate approximately symmetrically about a zero axis and approuch zero velucity at the end of lhe eartlrquake. A similar condition could not be ap- 
plied to the ground displacement since permanent ground displacements at the end of the eartlicuake could occur.

It has been shown by Hudson (') that the periods inturluced in the accelerogram by the parabolic base-line correction do not seriously aflect the accuracy of the response spectra calculations for periods ulp to about 5 sec. Also the parabolic base-line does not meet all of the requirements for the standard base-line correction, because it depends largely on the record length, and the low frequency components will be treated differently from one accelerogram to another.

If $u_{c}$ is the corrected acceleration and $u$ the uncorrecter acceleration by introducing the time tepentent second order polynomial we have:

$$
u_{\mathrm{c}}=\ddot{u}-\left(C_{1}+2 C_{\mathrm{a}} t+3 C_{3} t\right)
$$

hence

$$
\begin{aligned}
& \dot{u}_{c}=u-\left(C_{1} t+C_{2} t^{2}+C_{3} t^{3}\right) \\
& u_{c}=u-\left(\frac{1}{2} C_{1} t^{2}+\frac{1}{3} C_{-} t^{3}+\frac{1}{4} C_{3} t^{4}\right)
\end{aligned}
$$

where $\dot{u}_{c}, \dot{u}$ are the corrected and uncorrected ground velocities and $u_{c}, u$ wre the corrected and uncorrected ground displacements.

The minimization of the mean square ground velocity requires the quantity $P=\int_{0}^{s} \dot{u}_{c}{ }^{2} d t$ to be minimum.

So we have

$$
R=\int_{0}^{T} \dot{u}-\left(C_{1} t+C_{2} t^{2}+C_{3} t^{3}\right)^{2} d t \rightarrow \min .
$$

In accordance with the rules of partial differentiation

$$
\frac{\partial R}{\partial C_{1}}=0 \quad \frac{\partial R}{\partial C_{2}}=0 \quad \frac{\partial R}{\partial C_{3}}=0
$$

and the final condilions are

$$
\begin{aligned}
& \frac{T^{3}}{3} C_{1}+\frac{T^{4}}{4} C_{2}+\frac{T^{5}}{5} C_{3}=\int_{0}^{T} u t d t \\
& \frac{\mathrm{T}^{4}}{4} C_{1}+\frac{T^{5}}{5} C_{2}-\frac{T^{6}}{6} C_{3}=\int_{0}^{T^{\prime}} u t^{2} d t \\
& \frac{\mathrm{T}^{5}}{5} C_{1}+\frac{T^{6}}{6} C_{2}+\frac{T^{2}}{7} C_{3}=\int_{0}^{T} u t^{3} d t .
\end{aligned}
$$


Assuming initial conditions of zero velocity and displacement and with $\dot{u}$ and $T$ known the $C$ 's values can be evaluatel.

By this way the correcterl values of acceleration, velocity and displacement can be calculated. The above corrected quantities provide the basis of spectral calonlations which, as maximum response values can be expresserl in terms of accelemtion velocity and displacement for different rlampings.

In figs 11a and $11 \mathrm{~b}$ the relative displacement for different damping ratios are indicated for $\mathrm{E}-\mathrm{W}$ and $\mathrm{N}-\mathrm{S}$ components. In figs $12 \mathrm{a}$ and $12 \mathrm{~b}$ you can see, for the sume damping ratios, the relative velocities of the wo components and in figs $13 \mathrm{a}$ and $13 \mathrm{~b}$ the absolute accelerations. All these curves are valid for the main shock.

We applied the same technique to the acelerograms obtained during the larger aftershock and we have families of curves for the two horizontal components and the same damping ratios for the relative displacements, relative velocities ansl absolute accelerations.

These spectra are important for engineering purposes, since the acceleration spectra enable us to obtain the higher and lower frequencies of ground movement and the velocity spectra are relaterl to encrgy values which ean be used for rlesign purposes.

\section{7. - CoNclusions}

From the records of the main shock by seismoscopes we may conclude that the values attenute with distance in a fairly uniform way. It was impossible to investigate if the motions were more severe perpendicular to the fault than parallel to it.

From the power spectral density plots it was foum for the main shock that the prerlominant frequencies were $2 \mathrm{cps}$ for $\mathrm{E}-\mathrm{W}$ and $4 \mathrm{cps}$ for N-S component.

The ratio of the main shock predominant period to that of the late aftershock for $\mathrm{E}-\mathrm{W}$ component was found 1.34 and for N-S component was found 1.17. The absence of well expressed secondary maximum, for other period sthan the predominant one, for the late aftershock was attributed to the small duration of the record.

Since the initial veloeity and displacement and the actual zero base-line for the digitizer acelerngram are not known in order to produce grounl velocities and displacements with a satisfactory ac- 


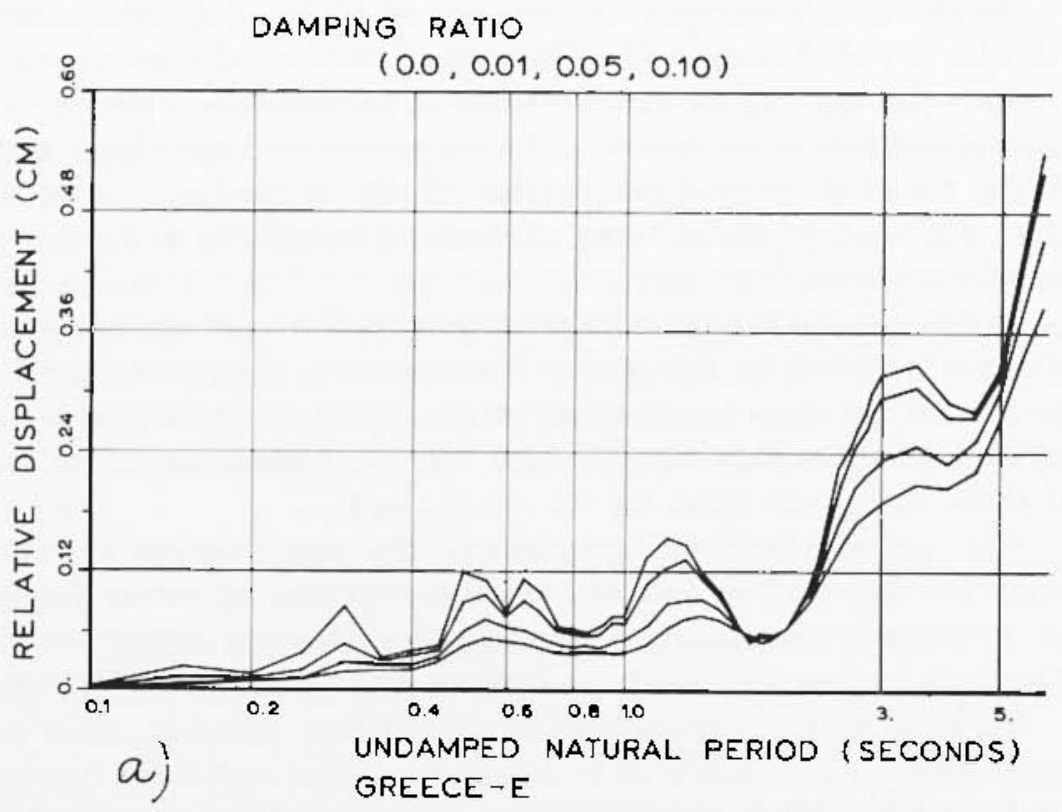

DAMPING RATIO

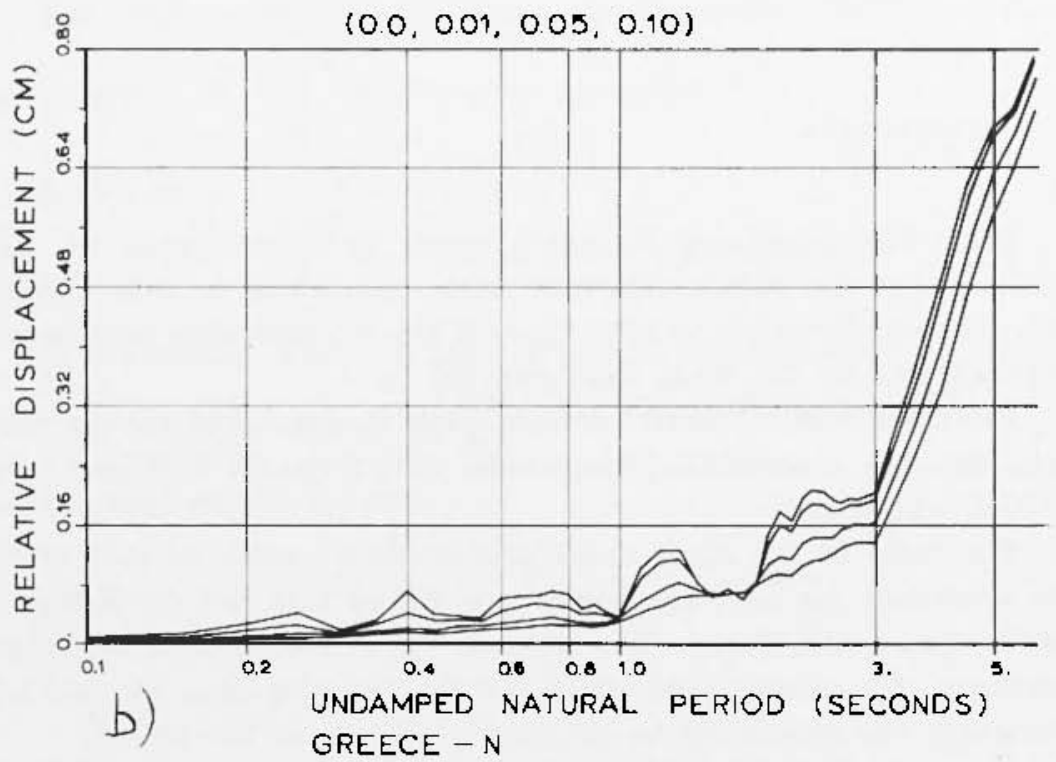

Fig. 11 - Relative displacements versus period and different dampingr ratios of the main shock for L.W (Ila) and N-S (Ilb) components. 

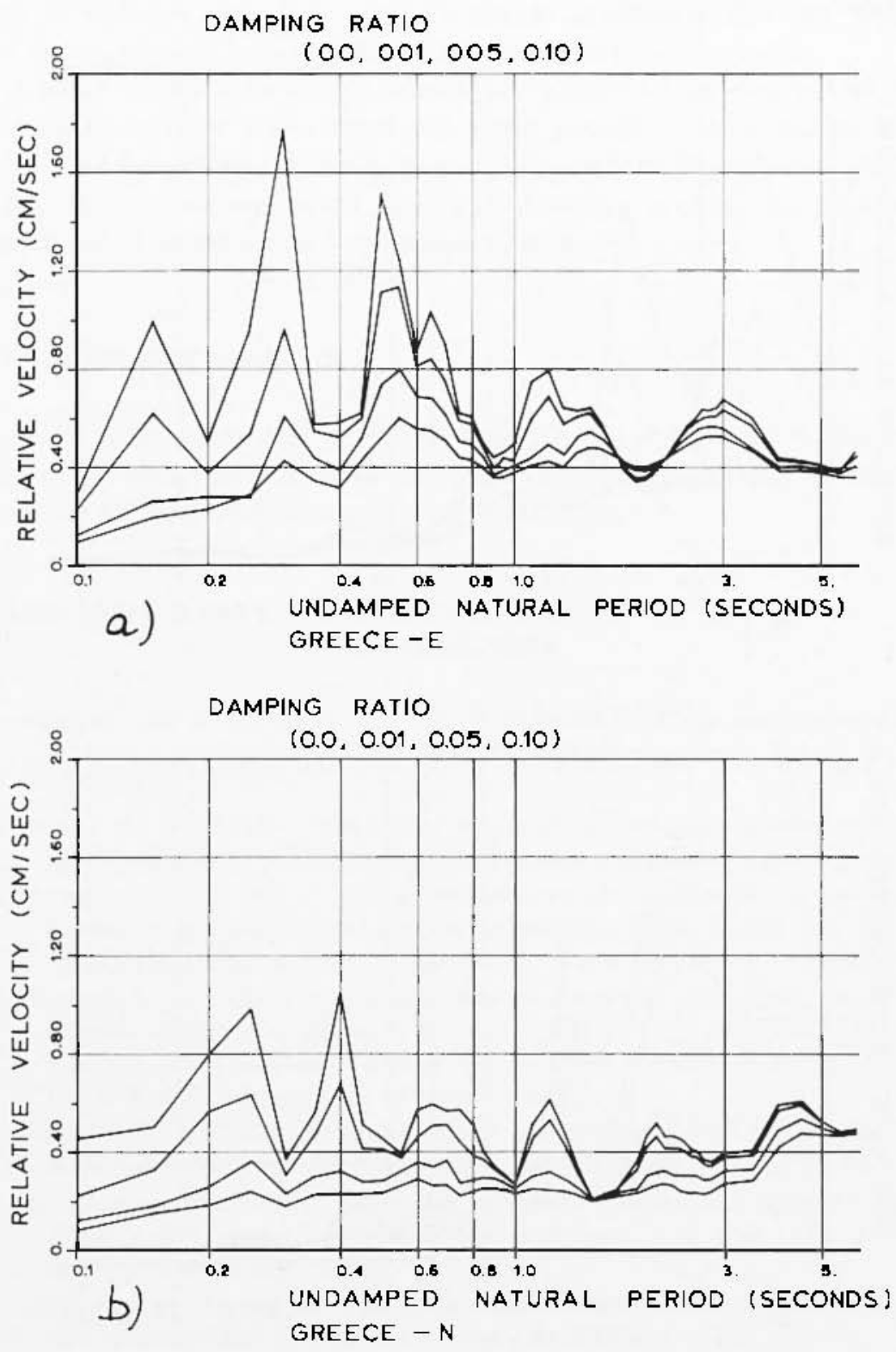

Fig. 12 - Relative velocities versus period and different damping ratios of the main shock for W.W (12a) and N-S (12b) components. 

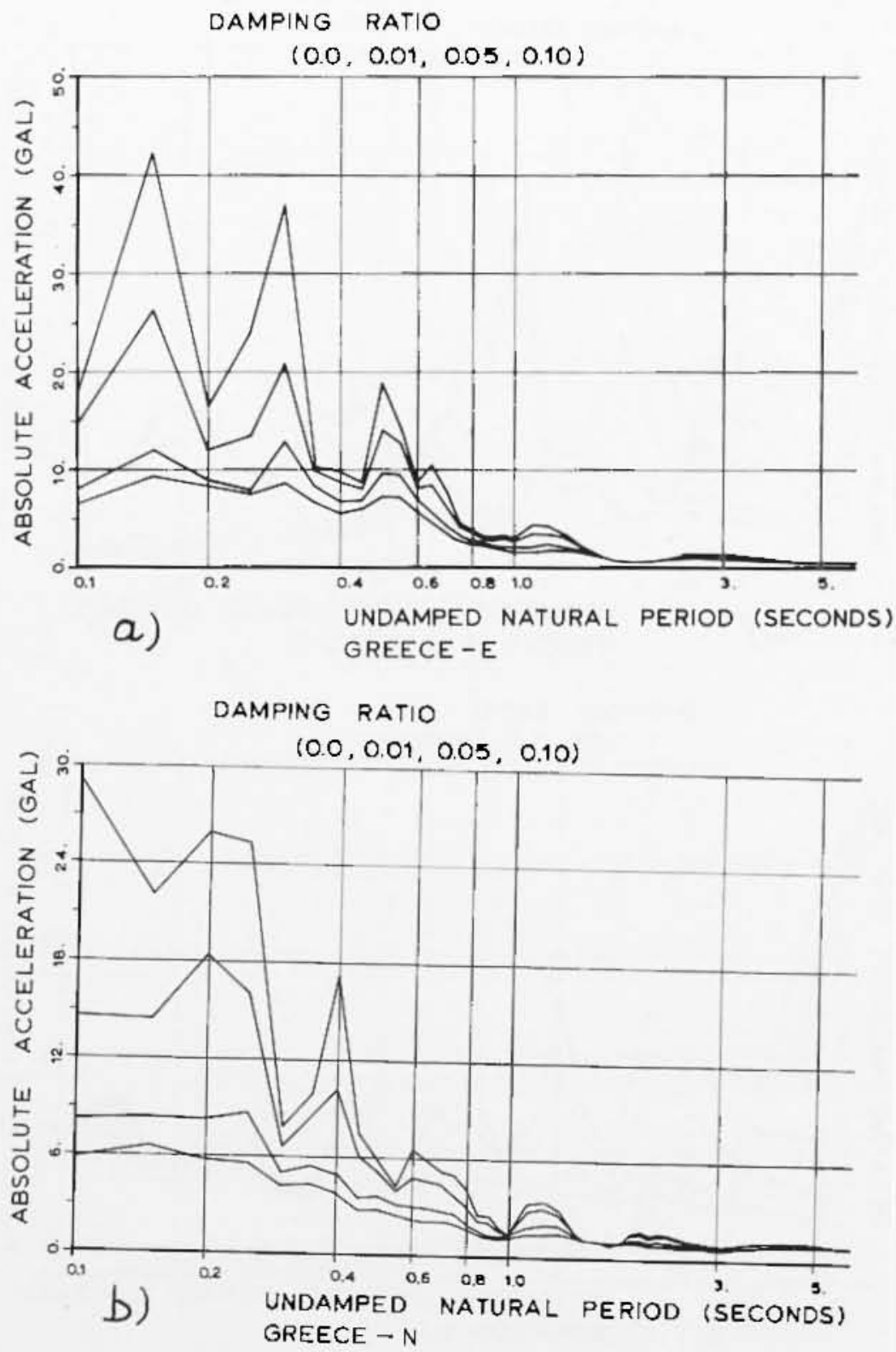

Fig. 13 - Absolnte accelerations versus period and different damping ratios of the main shock for E.W (13a) and N-S (13b) components. 
curacy we applied the least-mean-square-velocity tochnique which was introrluced by Berg and Housner (1). This techique malies the mean square value of the ground velocity a minimum.

Some useful information about the nature of the motion of the gromul have been taken from the main seismic characteristies such as: period-frequency analysis, probability density rlistribution, antocorrelation function, power spectral density, ground acceleration, velocity and displacement, res]onse spectra ete.

\section{8. - ACKXOWJEDGEMENTS}

The authors are very grateful to prof. $\Lambda$. G. Galanopoulos, University of Athens, for encourdagement and for providing the necessary facilities to carry out the present investigation.

\section{REFERENCES}

(1) Bend G. ani Housner G. W., 1961. - Integrated velocity and displacement of strong earthquake ground molion. "Bul. Scism, Soc. Am.", 51, 2, $175 \cdot 189$.

(2) BRADY A. G., 1966. - Studies of response to earlhquale ground molion. "California Inst. of Teehnology", Pasudena, California.

(3) Hudsox D. E., 1962. - Some problems in the application of spectrum. techniques to strong motion earthquake analysis. "Bul. Seism. Soc. Au..", $52,2,417 \cdot 430$.

(4) Hubson D. E., [971. - Strong motion instrumental data of the San Fermando earthquake of February 9, 1971. "Larth. Eng. Res. Lab. California Inst. of Technology and Seisun". Field Survey of the National Oceanic and Atmospheric Administration.

(5) Hubson I. E., 1972. - Strong motion Seismology. "Proecerl. of the In. tcrn. Conference on Microzonation", Seattle, USA, Yol, 1, 29-60.

(6) Roussoroclos A., 1971. - Fesponse analysis of sirong motion earlhquakes. Thesis subm. to the Imperial College of Science and Techn. for D.I.C. in Eng. Seismology, 1-128.

(7) Trifunac MI. D., 1971. - Zero bose-line correction of strong motion accolerogroms. "Bul. Scism. Soc. Am.", 61, 5, 1201-1211. 